Premise : Journal of English Education and Applied Linguistics

PJIEE https://fkip.ummetro.ac.id/journal/index.php/english

Nasution

\title{
THE MASS MEDIA'S LANGUAGE STYLES: ITS POWER AND APPROPRIATENESS FROM THE PERSPECTIVE OF SYSTEMIC FUNCTIONAL LINGUISTICS
}

\author{
Sukma Septian Nasution \\ UNIVERSITTAS PAMULANG, SOUTH TANGERANG \\ sseptiannasution@gmail.com
}

Accepted : January 1, 2018

Revised: January 19, 2018

Revised: February 8, 2018

Accepted: March 24, 2018

Published: April 2, 2018

\begin{abstract}
:
The role of mass media is inevitably significant for people's everyday life. As one of mass media, newspaper is very effective not only in informing the readers but also in influencing their principles and belief regarding to certain issues. However, texts published in newspapers potentially goes unsuitable for the targeted readers making its significance in informing and influencing less optimal. Accordingly, it is necessary to research the language styles of newspapers to optimize its power of significance in influencing the potential or targeted readers. This is a descriptive analysis study employing systemic functional linguistics (SFL) in analyzing the language styles of texts published by two popular mass media; The Jakarta Post and National Geographic. The analysis tools underpinned by SFL used in this study are the lexical system of congruency, lexicogrammar of complex-simplex clauses, conjunctive relations, and complexity of verbal and nominal groups of the news. The results show that (1) the targeted readers of the news are adult; (2) the use of incongruent lexis, internal conjunction, simple clause, complex group both verbal and nominal, and generic participant are more frequently employed; accordingly (3) written style is employed more often than spoken style. The findings drive to the conclusions that most of the news' language styles go appropriate to the targeted readers. It means that its power to inform and influence the readers goes optimal. However, the linguistic techniques need improving in order the texts sound more intelligible to the targeted readers.
\end{abstract}

Keywords: Linguistic Choices, Mass Media, Style 


\section{INTRODUCTION}

The eminent purpose of writing in mass media is to spread information to the readers. Accordingly, it is, as a writer, significant to concern with whether the text is intelligible to the readers or not. Text's intelligibility can be influenced by some factors. One of the factors is the language style of the text (Halliday, 1985).

Generally, there are two kinds of language style. They are written style and spoken style. Spoken style is often correlated to popular style (Carter, 1997) which is evidently easier to be understood by readers (Santosa, 2011). On the other hand, written style is commonly associated with high technicality; the usage of abstract nouns and other characteristics which make it has its own challenge to be understood by readers.

Further, spoken style does not always associate language used in oral form. In case there are two interlocutors talking about certain topic, it is incorrect to easily categorize that the style they communicate is spoken style. Vice versa, when we read a magazine, for instance, it does not mean that the text we are reading is a written-style text. There are some possibilities that the dialogue uses written language. On the other hand, a magazine can be a good example to a spoken-style. Therefore, it is interesting to find out to what style a text belongs. By finding out the style of a text, the social configuration is automatically figured out (Simpson, 2004) which enables us to determine the persons involved in the text (tenor), the topic being discussed (field) and the medium used (mode) such as emotions, (Suhandang, 2004) and (Passante, 2008). By bringing out the social context elements, it is then able to determine the appropriateness of the text to the targeted readers which at the end can aggrandize the quality of intelligibility of the text. This paper aims to find out the intelligibility of three texts taken from two popular mass media in Indonesia to each of their social configuration.

\section{The Nature of Spoken Style and Written Style}

Spoken style is not a language which is uttered and written language is not a language which is written (Santosa, 2011) rather states that spoken style is a product of thought while written language is the artifact (Coulmas (1992). Further, Halliday (1985a) and McCharty (1991) cited in Santosa (2011) believe that spoken language is used to act, think, and behave directly in a social process while written language is the 
representation of our thought, action, and behavior. Halliday (1985b) also believes that language style classification is not always rigid. It is hard to affirm a text as a totally spoken or written language text. In analyzing the style of texts whether they belong to spoken or written text, Kristina (2014) states that there are some crucial issues to be addressed as indicators of language competence of the users.

"Particularly, the spoken-style language or discourse is characterized by (1) adjacency pairs - it refers to pairs of utterance (greeting-greeting; apology-acceptance; congratulation-thanks). (2) exchanges - patterned exchanges in a conversational group. Hence, expressions like that's great, oh dear, luck you, dear John, alright, fantastic, how lovely, and so on often appears. It also is called with conventionalization; (3) turn-taking taking the floor (turn) to speak. The possible turn-shifting devices are 'may I interrupt? Hang on a minute, right, sure, oh-ha, that's it, etc.; (4) topics shifting - change of information flow where it is believed that those who have more power tend to shift the topic. So the expressions like by the way, anyway are commonly used; (5) interactional and transactional talk - lubricating the social wheels in order to establish roles and relationships, confirming, consolidating relationship, solidarity and empathy, and engaging others to do something or influencing others to suit the speaker's expectation; (6) awareness of discourse markers, and (7) speech and grammar- verb-less clauses, ellipses, lack of concord, false starts, slips of the tongue, etc.."

On the other hand, Santosa (2011) states that the differences of spoken style and written style are shown in table 1.

Table 1. The characteristics of spoken and written style

\begin{tabular}{|l|l|}
\hline \multicolumn{1}{|c|}{ Spoken Style } & \multicolumn{1}{c|}{ Written Style } \\
\hline $\begin{array}{l}\text { Using congruent lexical system; less abstraction } \\
\text { and technicality }\end{array}$ & $\begin{array}{l}\text { Using incongruent lexical system; more } \\
\text { abstraction and technicality }\end{array}$ \\
\hline $\begin{array}{l}\text { The lexico-grammatical use expresses two ways } \\
\text { interrelationship by using vocative, minor } \\
\text { clause, exclamation, and summoning second } \\
\text { persons: you, John, dear, etc. }\end{array}$ & No summoning of second persons \\
\hline Imperative & No imperative \\
\hline More use of external conjunctions & More use of internal conjunctions \\
\hline Repetition & Less repetition \\
\hline Ellipsis & Less ellipsis \\
\hline Minor clause & Less minor clause \\
\hline
\end{tabular}

From the two indicators above, there are many similarities of indicators given by the two experts. Accordingly, the writers synthesize them based on the most frequently appeared characteristics found in the analyzed texts. However, it does not 
mean that all the characteristics above are found in the text. The synthesis of style indicators is depicted in table 2 .

Table 2. Synthesizing the characteristics of language style

\begin{tabular}{l|l|l}
\hline No. & \multicolumn{1}{|c|}{ Spoken Styles } & \multicolumn{1}{|c}{ Written Styles } \\
\hline 1 & $\begin{array}{l}\text { The use of exchanges / } \\
\text { conventionalization by summoning } \\
\text { second persons; oh dear, luck you, dear } \\
\text { John, you, etc. }\end{array}$ & $\begin{array}{l}\text { The use of generic participants; the } \\
\text { scientists, the learners, etc. }\end{array}$ \\
\hline 2 & Using more complex sentences & Using more simplex sentences \\
\hline 3 & Using more simplex groups & Using more complex groups \\
\hline 4 & More use of external conjunctions & More use of internal conjunctions \\
\hline 5 & $\begin{array}{l}\text { Congruent lexis; less abstraction and } \\
\text { technicalities }\end{array}$ & $\begin{array}{l}\text { Incongruent lexis; more abstraction and } \\
\text { technicalities }\end{array}$ \\
\hline 6 & $\begin{array}{l}\text { More use of Repetition: } \\
\text { A: What is your name? } \\
\text { B: My name is Brenda } \\
\text { and ellipsis: } \\
\text { I have a book. I bought the book in the } \\
\text { famous book store. The book was so } \\
\text { expensive. }\end{array}$ & $\begin{array}{l}\text { Less use of repetition } \\
\text { A: What is your name? } \\
\text { B: Brenda } \\
\text { And less use of ellipsis }\end{array}$ \\
\hline
\end{tabular}

The analysis of complex sentence is by the logical meaning system and that of conjunction is by conjunctive relations system (Martin \& Rose, 2003) while the group to be analyzed is restricted to nominal group and verbal group. The analysis of logicosemantics sees a language from the entity of process constituent. A clause may have only one process which is then called as simplex. Those with two or more clauses are called complex. The complexity of a clause is viewed from its inter-pendency and relation. The inter-dependency varies into paratactic- two or more clauses can be separated and have parallel relation in which the way to analyze it is by $1,2,3 \ldots$ analysis. The other one, hypotactic - one or more clause should be dependent on the main clause, is analyzed by $\alpha, \beta \ldots$ analysis. The relation of the complexity varies into projection and expansion. Projection varies into locution (verbal projection) symbolized by (") and ideas (mental projection symbolized by (') (Rahmah, Gurning, \& Ginting, 2011). On the other hand, the conjunctive relations analysis views two clauses always have conjunction. They are the inter-clauses cohesive devices. There are two kinds of conjunction; explicit and implicit (Martin, 1997). Explicit means we can clearly see that the conjunction exists while the implicit conjunction cannot be seen but on the idea that two clauses should be logic, there must be an implicit conjunction (Santosa, 2011). The explicit one varies into conjunction, continuative, and metaphoric. 
Conjunction varies into external conjunction (to relate the event and quality of clauses) and internal conjunction (to organize the arguments/ideas). Continuative means that the conjunction comes along with the verb and metaphoric means the conjunction alters to be process, things, or circumstances (Santosa, 2011). The logical meaning system functions as a path to direct the writers to give decisions whether a sentence belongs to simplex or complex to judge the tendency of the language style- whether written or spoken.

\section{Objectives of this study}

The objectives of this study are to find out

1. who the targeted readers of the news;

2. the use of incongruent lexis, internal conjunction, simple clause, complex group both verbal and nominal, and generic participant;

3. which one is more used: the written style or the spoken style;

\section{METHODOLOGY}

This is a quantitative descriptive study which uses three texts from two popular mass media: National Geographic and The Jakarta Post as the samples to find out their intelligibility, power, and appropriateness to their readers through usage of language style. Decision whether a text belongs to spoken text or written text is generally taken from the dominant characters the text brings inside. To find out its dominant character, the analysis of language style is employed through register of discourse semantics level of systemic functional linguistics introduced by Halliday (1985b) which separates styles into spoken and written. Further, each utterance is analyzed not only in the level of linguistics unit but also its reasonable choices of using such kind of language style.

\section{FINDINGS AND DISCUSSION}

\section{Text 1: Written-Style}

After analyzing the clause system of the text, the complexity of the groups, verbal group, noun group, and other indicators to specify whether the text is classified into written or spoken text, it is decided that the first text belongs to the written language. By written text, it means that the dominant characteristics the text brings in 
terms of language style tends to written style rather than spoken style. To find out the result of analyzing the text, table 3 shows complete analysis of why it belongs to written text.

Table 3. The Analysis to Text 1

\begin{tabular}{|c|c|c|c|}
\hline No. & $\begin{array}{l}\text { The Found- } \\
\text { Characteristics }\end{array}$ & Examples & Description \\
\hline 1 & $\begin{array}{l}\text { The use of } \\
\text { summoning } \\
\text { general } \\
\text { participants }\end{array}$ & $\begin{array}{l}\text { construction workers the local } \\
\text { government and Ottoman officials } \\
\text { scientists Muslim invaders } \\
\text { Geophysicists, etc. }\end{array}$ & $\begin{array}{l}\text { Instead of using specific } \\
\text { participants such as you, John, the } \\
\text { man, written-style text mostly } \\
\text { prefer the use of general } \\
\text { participants. }\end{array}$ \\
\hline 2 & $\begin{array}{l}\text { No imperative; } \\
\text { tend to be } \\
\text { declarative }\end{array}$ & $\begin{array}{l}\text { All the sentences are grammatically } \\
\text { declarative whose speech function is } \\
\text { to give information. }\end{array}$ & \\
\hline 3 & $\begin{array}{l}\text { Grammatical } \\
\text { Intricacies: More } \\
\text { simplex } \\
\text { sentences }\end{array}$ & $\begin{array}{l}\text { Among } 21 \text { clauses inside the text, } \\
\text { there are } 13 \text { simplex clauses } \\
\text { strengthening that the tendency of } \\
\text { using written language/style is used } \\
\text { by the author. }\end{array}$ & The analysis is provided above. \\
\hline 4 & $\begin{array}{l}\text { Grammatical } \\
\text { Intricacies: } \\
\text { More complex } \\
\text { groups: } \\
\text { (4) for nominal } \\
\text { and (4a) for } \\
\text { verbal }\end{array}$ & $\begin{array}{l}\text { Mostly, the groups are complex } \\
\text { signified from the fulfillment of the } \\
\text { element of the nominal groups as } \\
\text { shown in the analysis above and the } \\
\text { italic groups in each written-style } \\
\text { texts. }\end{array}$ & \\
\hline 5 & $\begin{array}{l}\text { More use of } \\
\text { internal } \\
\text { conjunctions }\end{array}$ & $\begin{array}{l}\text { 1.It is still largely unexplored, but } \\
\text { initial studies suggest its size and } \\
\text { features may rival those of the largest } \\
\text { excavated underground city in } \\
\text { Cappadocia, which could house } \\
20,000 \text { people. } \\
\text { 2."We found documents stating that } \\
\text { there were close to } 30 \text { major water } \\
\text { tunnels in this region," says Nevşehir } \\
\text { mayor HasanÜnver. } \\
\text { 3.They estimate (that) the site is } \\
\text { nearly five million square feet } \\
\text { (460,000 square meters) among } 33 \\
\text { independent measurements. }\end{array}$ & $\begin{array}{l}\text { The underlined words are devices } \\
\text { to show arguments as the mark of } \\
\text { signifying the existence of } \\
\text { internal conjunction (relating two } \\
\text { or more arguments in two or more } \\
\text { clauses). }\end{array}$ \\
\hline 6 & $\begin{array}{l}\text { Lexis: } \\
\text { Abstraction and } \\
\text { Technicalities }\end{array}$ & $\begin{array}{l}\text { Unearthed, linseed otherworldly } \\
\text { chimney house, cave churches }\end{array}$ & $\begin{array}{l}\text { The words are so technical where } \\
\text { average person find hard to } \\
\text { understand, another characteristic } \\
\text { of written-style text }\end{array}$ \\
\hline
\end{tabular}




\begin{tabular}{|c|c|c|c|}
\hline 7 & $\begin{array}{l}\text { The use of major } \\
\text { clause }\end{array}$ & $\begin{array}{l}\text { Among } 21 \text { sentences, there are only } \\
\text { two minor clauses as stated in the } \\
\text { analysis.. }\end{array}$ & \\
\hline 8 & $\begin{array}{l}\text { The use of } \\
\text { Metaphorical } \\
\text { Conjunctive } \\
\text { Relations and } \\
\text { Grammatical } \\
\text { Metaphor }\end{array}$ & 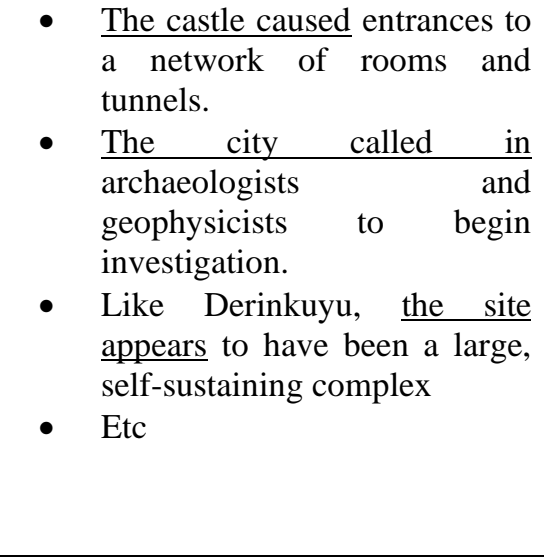 & $\begin{array}{l}\text { Metaphorical conjunction is a } \\
\text { marked-diction as it alters the } \\
\text { original function of conjunction } \\
\text { into process like caused, } \\
\text { appears, etc in to verb, into } \\
\text { circumstance, and into subject } \\
\text { also. } \\
\text { One of the characteristics of } \\
\text { grammatical metaphor is to } \\
\text { personify the non-person objects } \\
\text { by attaching them with verb like } \\
\text { called, caused, etc. it is } \\
\text { impossible that the city can do a } \\
\text { call where usually human does it. }\end{array}$ \\
\hline
\end{tabular}

However; this finding has not yet been confirmed with the previous similar topic due to limited resources to get. Therefore; whether the conclusion of this finding is worse, similar or better remains unclear.

\section{Text 2: spoken style}

After analyzing the clause system of the text, the complexity of the groups contended, and other indicators to specify whether the text is classified into written or spoken text, we decide that the first text belongs to the spoken language. The complete analysis is shown in this table 4 .

Table 4. The Analysis to Text 2

\begin{tabular}{l|l|l}
\hline No. & \multicolumn{1}{|c|}{ Characteristics } & \multicolumn{1}{c}{ Examples } \\
\hline 1. & $\begin{array}{l}\text { The use of summoning } \\
\text { of second person; }\end{array}$ & You \\
\hline 2. & Imperative & $\begin{array}{l}\text { 1.Imagine the conversation in, say, the year 2100 } \\
\text { 2.Come out with your hands up and check out these items } \\
\text { available at a low, low price if you act now }\end{array}$ \\
\hline 3. & $\begin{array}{l}\text { Grammatical } \\
\text { intricacies; more } \\
\text { complex sentences; } \\
\text { simplex groups. }\end{array}$ & $\begin{array}{l}\text { Simplex : 10 sentences. } \\
\text { Complex : 13 sentences. }\end{array}$ \\
\hline 4. & $\begin{array}{l}\text { More use of external } \\
\text { conjuctions }\end{array}$ & $\begin{array}{l}\text { 1. Police are on my mind after a reader sent me a news item } \\
\text { about cops who raided a brothela few days ago and found } \\
\text { four colleagues using it. } \\
\text { 2. "Come out with your hands up and check out these items } \\
\text { available at a low, low price if you act now." }\end{array}$ \\
\hline
\end{tabular}




\begin{tabular}{l|l|l}
\hline & & $\begin{array}{l}\text { 3. Meanwhile, if police do stop you for speeding, I can } \\
\text { certify that attempts to talk your way out of trouble with } \\
\text { science don't work. Etc. }\end{array}$ \\
\hline 5. & $\begin{array}{l}\text { Lexis: Proper to } \\
\text { average persons }\end{array}$ & $\begin{array}{l}\text { car, radio, heart attack, song, traffic, news, officers, } \\
\text { assignment, murderer, jail. Etc }\end{array}$ \\
\hline 6. & Repetition & $\begin{array}{l}\text { 1.The really, really bad thing was that during the arrests, } \\
\text { murderer BaijuYadav slipped away into the nearby } \\
\text { township. } \\
\text { 2.The really, really, really bad thing was that the murderer } \\
\text { voluntarily returned to the prison. }\end{array}$ \\
\hline 7. & Ellipsis & Wonder what his standard line was? \\
\hline 8. & Minor clause & Worrying tales of the world's worst cops. \\
\hline 9. & Conventionalize & Wonder what his standard line was? \\
\hline
\end{tabular}

However; this finding has not yet been confirmed with the previous similar topic due to limited resources to get. Therefore; whether the conclusion of this finding is worse, similar or better remains unclear.

\section{Text 3: Written Style}

After analyzing the clause system of the text, the complexity of the groups contended, and other indicators to specify whether the text is classified into written or spoken text, we decide that the first text belongs to the written language. The complete analysis is shown in this table 5 .

Table 5. The Analysis to Text 3

\begin{tabular}{c|l|l}
\hline No. & Characteristics & \multicolumn{1}{c}{ Examples } \\
\hline 1 & $\begin{array}{l}\text { The use of summoning } \\
\text { general participants }\end{array}$ & $\begin{array}{l}\text { Passengers, pilots, people, flying crew, cabin members, } \\
\text { safeguards, crew members, human. }\end{array}$ \\
\hline 2 & $\begin{array}{l}\text { No imperative; tend to be } \\
\text { declarative }\end{array}$ & $\begin{array}{l}\text { All the sentences are grammatically declarative whose } \\
\text { speech function is to give information. }\end{array}$ \\
\hline 3 & $\begin{array}{l}\text { Grammatical Intricacies: } \\
\text { More simplex sentences }\end{array}$ & $\begin{array}{l}\text { Among 40 clauses inside the text, there are 21 simplex } \\
\text { clauses strengthening that the tendency of using written } \\
\text { language/style is used by the author. }\end{array}$ \\
\hline 4 & $\begin{array}{l}\text { Grammatical Intricacies: } \\
\text { More complex groups } \\
\text { (4) for nominal and (4a) for } \\
\text { verbal }\end{array}$ & $\begin{array}{l}\text { Mostly, the groups are complex signified from the } \\
\text { fulfillment of the element of the nominal groups as } \\
\text { shown in the analysis above. }\end{array}$ \\
\hline
\end{tabular}




\begin{tabular}{c|l|l}
\hline 5 & $\begin{array}{l}\text { More use of internal } \\
\text { conjunctions }\end{array}$ & $\begin{array}{l}\text { 1.I wouldn't be surprised if passengers now insist on } \\
\text { pilots' health checkups being put up in public domain. } \\
\text { 2.From what I understand, piloting a plane on a clear } \\
\text { sky with everything going fine is a very boring activity }\end{array}$ \\
\hline 6 & $\begin{array}{l}\text { Incongruent Lexis: } \\
\text { Abstraction and } \\
\text { Technicalities }\end{array}$ & $\begin{array}{l}\text { The terrain, fortress, bulletproof doors, low-tech } \\
\text { latches, traditional keys. }\end{array}$ \\
\hline 7 & The use of major clause & $\begin{array}{l}\text { Among 40 sentences, there are only three minor clauses } \\
\text { as stated in the analysis under this table. }\end{array}$ \\
\hline 8 & $\begin{array}{l}\text { The use of Metaphorical } \\
\text { Grammatical Metaphor }\end{array}$ & $\begin{array}{l}\text { 1. The mystery surrounding the Germanwings Flight } \\
\text { 4U 9525 seems to have unravelled finally. } \\
\text { 2. The mental trauma this tragedy has generated will } \\
\text { affect millions of airline passengers across the world. } \\
\text { 3. If memory serves me right, there were no doors } \\
\text { between the cockpit and passenger seats - only } \\
\text { curtains. } \\
\text { 4. Perhaps the health checkups for flying crew and } \\
\text { cabin members need to be upgraded. }\end{array}$ \\
\hline
\end{tabular}

The whole findings have not been compared with the prior studies; consequently, whether the current study is consistent, better or worse are questionable due to inadequate sources taken into account.

\section{CONCLUSIONS AND SUGGESTIONS}

\section{Conclusion}

The analysis of the three texts taken from three different popular mass media reveal to some conclusions that (1) text 1 has written style; text 2 has spoken style; and text 3 has written style which conclude that (2) among the three texts, text 2 is the one which gives high intelligibility to the readers as it is to approach spoken style. However, the three texts mostly (3) contain jargons or technical wordings which are still not common to the average readers.

\section{Suggestion}

The suggestions to the mass media are (1) the tendency of using spoken style should be more than that of written style to provide average readers intelligible 
information; (2) mass media should provide the readers explanation of technical words in order that they find it easy to understand the text as a whole.

This study is limited to three sources of media and there aspects of focused analysis. Future studies are recommended to take broaden media and deep aspects of analysis among the factual contents of the targeted media.

\section{BIO-PROFILE}

Sukma Septian Nasution is an active lecturer at Universitas Pamulang, South Tangerang and Sekolah Tinggi Bahasa Asing Lembaga Indonesia - Amerika (STBA LIA) Jakarta, Indonesia. He graduated from undergraduate program of English Education of Universitas Negeri Medan. He is also a master graduate of English Education of Universitas Sebelas Maret, Surakarta. His research areas mainly focus on

Language Teaching, Language Skills, Critical Discourse Analysis, and Applied Linguistics. 


\section{REFERENCES}

Carter, R. (1997). Investigating English Discourse: Language, literary, and literature. London: Routledge.

Coulmas, F. (1992). The Writing System of the World. Oxford: Blackwell.

Halliday, M.A.K. (1985b). Spoken and Written Language. Victoria: Deakin University Press.

Kristina, Diah. (2014). Discourse Analysis. Surakarta: Universitas Sebelas Maret.

Martin, J.R. (2002). Meaning Beyond the Clause: SFL Perspectives. Annual Review of Applied Linguistics, 6(8), 52-74. Cambridge University Press.

Martin, J.R. \& Rose, D. (2003). Working with Discourse: Meaning Beyond the Clause. London: Continuum.

McCarthy, M. (2001). Ten Criteria for Spoken Grammar: New Perspectives on Grammar Teaching in Second Language Classrooms, 2(4), 51-75 Lawrence Erlbaum Associates.

Passante, C.K. (2008). The Complete Ideal's Guids: Journalism. Jakarta: Prenada.

Rahmah., Gurning, Busmin., Ginting, Immanuel,. Prasetya. (2011). Functional Grammar. Medan: Universitas Negeri Medan

Santosa, Riyadi. (2011). Logika Wacana. Surakarta: UNS PRESS.

Simpson, P. (2004). Stylistics: A Resource Book for Students. London: Routledge.

Suhandang, K. (2004). Pengantar Jurnalisme: Seputar Organisasi, Produk, \& Kode Etik. (Introduction to Journalism: Organizaion, Products, and Codes of Ethics). Bandung: Nuansa. 